\title{
Appraisal of Pollution and Source Apportionment of Potentially Toxic Elements in Different Soils Collected around the Industrial Area
}

\section{Falwinder Verma}

IKGPTU: IK Gujral Punjab Technical University Jalandhar

Salwinder Singh Dhaliwal

Punjab Agricultural University

\section{Vinod Kumar}

Government Degree College, Ramban

\section{Rakesh Kumar}

Doaba College

Jaswinder Singh ( $\square$ singhjassi75@yahoo.co.in )

Khalsa College Charitable Society https://orcid.org/0000-0003-3178-0516

Chander Parkash

IKGPTU: IK Gujral Punjab Technical University Jalandhar

Sharanpreet Singh

Guru Nanak Dev University

\section{Research Article}

Keywords: Potentially toxic elements, multivariate statistical analysis, ecological risk assessment, geoaccumulation index

Posted Date: February 19th, 2021

DOI: https://doi.org/10.21203/rs.3.rs-214369/v1

License: (c) (1) This work is licensed under a Creative Commons Attribution 4.0 International License. Read Full License 

different soils collected around the industrial area

3

Falwinder Verma ${ }^{1,2}$, Sharanpreet Singh ${ }^{3}$, Vinod Kumar ${ }^{4}$, Rakesh Kumar ${ }^{5}$, Jaswinder Singh ${ }^{6 *}$, Chander Parkash $^{1}$, Salwinder Singh Dhaliwal ${ }^{7}$

${ }^{1}$ Department of Applied Sciences, I.K.G. Punjab Technical University, Kapurthala, Punjab, India-144603

${ }^{2}$ Department of Zoology, Government College for Girls, Ludhiana, Punjab, India-141001

${ }^{3}$ Department of Botanical \& Environmental Sciences, Guru Nanak Dev University, Amritsar, Punjab, India-143005

${ }^{4}$ Department of Botany, Government Degree College, Ramban, Jammu \& Kashmir, India182144

${ }^{5}$ Department of Botany, Doaba College, Jalandhar, Punjab, India-144004

${ }^{6}$ Post Graduate Department of Zoology, Khalsa College, Amritsar, Punjab, India-143001

${ }^{7}$ Department of Soil Science, Punjab Agricultural University, Ludhiana, Punjab, India141004

*Corresponding Author

Dr. Jaswinder Singh

Email: singhjassi75@yahoo.co.in 


\section{Abstract}

It is imperative to understand the pollution of potentially toxic elements (PTEs) in different soils in order to determine the sustainable management approaches for soils. Potentially toxic elements ( $\mathrm{Fe}, \mathrm{Mn}, \mathrm{As}, \mathrm{Pb}, \mathrm{Zn}, \mathrm{Ni}, \mathrm{Cu}, \mathrm{Cn}, \mathrm{Co}$ and $\mathrm{Cd}$ ), and $\mathrm{pH}$ and organic carbon were determined in agricultural, non-agricultural and industrial soils of Indian, Punjab. The findings of PTEs indicated that industrial soils recorded highest concentration of PTEs followed by non-agricultural and agricultural soils. The percentage change recorded from agricultural to non-agricultural soils for PTEs were 3.19\% for $\mathrm{Fe}, 25.3 \%$ for $\mathrm{Mn}, 63.8 \%$ for $\mathrm{Cu}, 13.5 \%$ for $\mathrm{Cn}, 49.8 \%$ for $\mathrm{Pb}, 79.6 \%$ for $\mathrm{Ni}, 35.8 \%$ for $\mathrm{Co}$ and $32 \%$ for $\mathrm{Cd}$. From nonagricultural to industrial soils the percentage change observed for PTEs were $89 \%$ for $\mathrm{Zn}$, $2.03 \%$ for $\mathrm{Fe}, 21.9 \%$ for $\mathrm{Mn}, 68.2 \% \mathrm{Cu}, 9.2 \%$ for $\mathrm{Cn}, 35.8 \%$ for $\mathrm{Pb}, 18.4 \%$ for $\mathrm{Co}, 30.4 \%$ for $\mathrm{Cd}$ and $43.4 \%$ for As. The results of contamination factor, enrichment factor, geoaccumulation index, pollution and modified pollution indices indicated that $\mathrm{Cd}$ and $\mathrm{As}$ showed severe contamination in all studied soil types. Ecological risk assessment results revealed that $\mathrm{Cd}$ exhibited very risk in different soil types. The outcomes of this study will aid in forming approaches to decline the perils allied with PTEs in soils, and produce guidelines to save the environs from long term accrual of PTEs. assessment, geoaccumulation index 


\section{Introduction}

Soil is considered as one of the most substantive non-renewable natural resource that supports plethora of flora as well as fauna (Jansson \& Hofmockel, 2019). Unfortunately, unsustainable development models are degrading agricultural soils at an alarming rate (Kopittke et al., 2019). Soil receives a lot of pollutants from diverse sources related to agriculture and other industries (Naveedullah et al., 2013; Kumar et al., 2019a). The rapid and incessant usage of inorganic pesticides, herbicides etc., has led to degradation of major agricultural edaphic system. Automobiles and other transportation systems also pollute the nearby fields (Kumar et al., 2019b). Amid other unwanted contaminants, heavy metals (HMs) form major pollutants having the starkest impact of plants. Industrial effluents rich in different kinds of heavy metals also reach soil either through water used for irrigation purposes or other anthropogenic activities.

HMs have high atomic density with atomic number more than 20. Being nondegradable, they persist in soil for very long duration of time (Mahey et al., 2020). Present global agricultural requirement pressurises producers to increase yield that induces involvement of unsustainable methods like HM based mineral phosphate fertilizers. Other HMs pollution sources are rune water from minning area, sewage disposal, smelting, and cement manufacturing etc., (Walter et al., 2006; Ohunkunle \& Fatoba, 2013). These HMs are taken up by crop plants and reach humans in biomagnified levels which pose a great risk to humans as is evident from increased number of pathological issues related with kidneys, liver, bone, pancreas etc. (Kawatra \& Bakhetia, 2008). Piling up of HMs in soil is a major hurdle in achieving global food safety. Most of the developing cities, due to fast development, are unable to curb this menace and face major edaphic degradation due to accumulation of HMs. 
The district Ludhiana of Punjab is known as industrial hub and also famously known

as Manchester of India (Sikka \& Nayyar, 2016). The town is famous for bicycle, woollen, hosiery, machine tools, dying and electroplating work. These industries generate huge amount of industrial effluents that are directly poured into tributary Budda Nullah through sewers. The untreated water of Budda Nullah is used to irrigate crop fields (Sikka et al., 2009). The waste reaching soil keeps on accumulating as HMs cannot be degraded or destroyed. Both essential and on essential HMS are considered toxic for terrestrial and aquatic organisms. There abundance more than threshold level cause ecological imbalance.

Keeping this thing in mind, the present work was conducted to appraise the potentially toxic elements (Fe, $\mathrm{Mn}, \mathrm{As}, \mathrm{Pb}, \mathrm{Zn}, \mathrm{Ni}, \mathrm{Cu}, \mathrm{Cn}, \mathrm{Co}$ and $\mathrm{Cd}$ ) and, $\mathrm{pH}$ and $\mathrm{OC}$ in agricultural, non-agricultural and industrial soils of Ludhiana, Punjab, India. Secondly, correlation analysis, principal component analysis and non-metric multidimensional scaling were performed to find the sources of PTEs. Lastly, pollution level and risk appraisal were determined by enumerating contamination indices and ecological risk assessment indices.

\section{Material and methods}

\subsection{Study area}

Soil samples were collected in triplicate from all over Ludhiana district of Punjab, India during May 2017 to October 2019 (Supplementary Table S1). The sample collection site map can be observed in Fig. 1. The mean temperature and humidity during collection was $35-42^{\circ} \mathrm{C} \& 58.1$ respectively (Kumar et al., 2010). Ludhiana district has climatic conditions of humid subtropical as per koppen climatic classification (Yeotikar et al., 2019). The mean rainfall is $758 \mathrm{~mm} / \mathrm{yr}$ (Hadda et al., 2020). Ludhiana is situated in the middle of Punjab and comes under Malwa sub region. The soil of Ludhiana has a loamy texture. According to 2011-20 census, the total area of Ludhiana was 3, 57, 800 hectares and total population was $34,98,739$. 


\subsection{Collection of samples}

Five hundred gram of soil was collected from each site in triplicates. Soil samples were dried and powdered to nullify the effect of particle size during analysis. The samples were properly coded and stored till further analysis.

\subsection{Analysis of soils for $\mathrm{pH}, \mathrm{OC}$ and potentially toxic elements}

Soil samples were analysed for $\mathrm{pH}$, OC and heavy metal content. Soil $\mathrm{pH}$ was measured following the method of Jackson (1967). Organic carbon from soil samples was estimated by the method given by Nelson and Sommers (1996). Heavy Metal estimation was done using Varian 20 model of atomic absorption spectrophotometer. Samples were digested using diacid mixture $\left(\mathrm{HClO}_{4}: \mathrm{HNO}_{3}\right.$ in $4: 1$ ratio).

\subsection{Computation of pollution indices}

To determine the pollution level of PTEs in soils various indices have been proposed by different workers. The computation of indices is as:

\subsubsection{Contamination factor $(\mathrm{CF})$}

The CF signifies the anthropogenic inputs in the soils and computed by dividing the PTEs level in determined samples to reference environment value (Hakanson 1980). The equation used to determine $\mathrm{CF}$ is as:

$\mathrm{CF}=\frac{\text { Concentartion of each PTE }}{\text { Background value of each PTE }}$

\subsubsection{Enrichment factor (EF)}

EF was used to find the natural and human impacts on PTEs concentration (Delgado et al. 2010) and computed as:

$\mathrm{EF}=\frac{\text { Concentartion of PTE in samples/Fe concentration in the samples }}{\text { Background values of PTE/Background value of Fe }}$ 
117 the scores used to classify the pollution level on $\mathrm{CF}$ and $\mathrm{EF}$ values were provided in 118 supplementary Table S2.

\subsubsection{Geoaccumulation index (Igeo)}

Igeo index indomitable the pollution of PTEs in soils and computed by following Muller et al. (1981) as:

$$
\text { Igeo }=\log _{2} \frac{\text { Heavymetal concentration in soil samples }}{1.5 \times \text { heavymetal concentration in backgroundenvironment }}
$$

The reference values of PTEs were adapted from Taylor and McLennan (1995). The constant 1.5 implies alterations in heavy metal concentrations in the environs (Tian et al. 2017).

\subsubsection{Pollution index (PI) and modified pollution index (MPI)}

The PI was computed by considering average and maximum value of $\mathrm{CF}$ for apiece PTE, while MPI takes into consideration the mean and maximum value of EF for apiece PTE. The PI and MPI were enumerated by ensuing Nemerow (1991):

$$
P I=\sqrt{\frac{\left(C F_{\text {average }}\right)^{2}+\left(C F_{\text {maximum }}\right)^{2}}{2}}
$$

$$
M P I=\sqrt{\frac{\left(E F_{\text {average }}\right)^{2}+\left(E F_{\text {maximum }}\right)^{2}}{2}}
$$

The grades used to categorize the pollution level are given in Supplementary Table S3.

\subsubsection{Ecological risk indices (RI and MRI)}

The ecological peril in the soils was resolute by using potential and modified ecological risk indices. The potential and modified risk indices were enumerated by taking into account the $\mathrm{CF}$ and EF values of PTEs respectively and determined as:

$$
\mathrm{RI}=\sum \mathrm{CF} \times \mathrm{Tr}
$$

$$
\mathrm{MRI}=\sum \mathrm{EF} \times \operatorname{Tr}
$$


Where $\mathrm{Tr}$ is the toxic response factor of apiece PTE adapted from (Heidari et al. 2019). The scores used to classify the ecological hazard are specified in Table S4.

\subsection{Statistical analysis}

All the analysis was performed in triplicates and data was presented as minimum, maximum, mean, standard error, variance, skewness, kurtosis and coefficient of variance. After that Pearson's correlation analysis was performed on the data to determine the sources among PTEs in soils using R software v3.0 (Statistical Computing, Vienna, Austria). Cluster analysis and principal component analysis was performed to find source apportionment among PTEs in soils using Minitab v.14 and SPSS v.16 software (IBM, USA). Lastly, nonmetric multidimensional scaling (NMDS) was conducted and it is a data reduction and score based technique for graphical depiction of the connotations amid PTEs in a multidimensional space, and performed by using PAST v.3.21 (Hammar et al. 2001).

\section{Results and discussion}

\subsection{Statistical analysis of potentially toxic elements in different soils and their comparison with soil guidelines}

The descriptive statistical analysis of pH, organic carbon (OC) and PTEs ( $\mathrm{Zn}, \mathrm{Fe}, \mathrm{Mn}$, $\mathrm{Cu}, \mathrm{Cn}, \mathrm{Pb}, \mathrm{Ni}, \mathrm{Co}, \mathrm{Cd}$ and $\mathrm{As}$ in agricultural, non-agricultural and industrial soils were given in Table 1. The $\mathrm{pH}$ was found in the range of 6.88 to 7.73 with average value of 7.46 in agricultural soils. In agricultural soils $\mathrm{pH}$ ranged from 7.4 to 7.73 , while in industrial soils $\mathrm{pH}$ ranged from 7.42 to 7.92 . The $\mathrm{pH}$ was found slightly acidic to alkaline in the present study which is associated with reduction of PTEs mobility in the soil (Heidari et al. 2019). Our results are in corroboration with Dogra et al. (2020) in Jalandhar, Punjab, and Keshavarzi and Kumar (2019b) in Iran, and in their findings they also reported similar results of $\mathrm{pH}$. The OC ranged from 0.04 to $1.35 \%$ in agricultural soils, 0.39 to $1.11 \%$ in non-agricultural soils and 0.42 to $1.42 \%$ in industrial soils and also has pronounced provocation on the transport of PTEs in all the studied soils (Troeh and Thompson 2005). The mean concentration of PTEs in 
agricultural soils followed a trend: $\mathrm{Fe}>\mathrm{Mn}>\mathrm{As}>\mathrm{Pb}>\mathrm{Cn}>\mathrm{Cu}>\mathrm{Ni}>\mathrm{Co}>\mathrm{Cd}$. Similarly average values of PTEs in non-agricultural and industrial soils followed the trend as: Fe > As $>\mathrm{Mn}>\mathrm{Pb}>\mathrm{Cu}>\mathrm{Ni}>\mathrm{Cn}>\mathrm{Co}>\mathrm{Cd}$, and $\mathrm{Fe}>\mathrm{As}>\mathrm{Mn}>\mathrm{Ni}>\mathrm{Pb}>\mathrm{Cu}>\mathrm{Cn}>\mathrm{Co}>\mathrm{Cd}$ respectively. After comparison of PTEs of agricultural soils with Indian background soils, it was inferred that $97.5 \%, 82.5 \%, 47.5 \%, 100 \%$ and $42.5 \%$ sampling sites surpassed their contents for $\mathrm{Zn}, \mathrm{Mn}, \mathrm{Ni}, \mathrm{Pb}$ and Co respectively (Gowd et al. 2010). Arsenic concentration exceeded $75 \%$ in contrast with Poland soil guidelines, while Cd concentration found low in comparison with their limits (Wcisło 2012). Similarly comparison of PTEs in nonagricultural soils with Indian background values and Poland soil limits indicated that $100 \%$ sampling sites surpassed their values for $\mathrm{Zn}, \mathrm{Mn}, \mathrm{Pb}, \mathrm{Ni}$, Co and As (Gowd et al. 2010; Wcisło 2012). In industrial soils, PTEs exceeded $100 \%$ for $\mathrm{Zn}, \mathrm{Mn}, \mathrm{Pb}, \mathrm{Ni}$, Co and As, while $80 \%$ for $\mathrm{Cu}$, and $60 \%$ for $\mathrm{Cd}$ in contrast with Indian background values and Poland soil limits (Gowd et al. 2010; Wcisło 2012).

The percentage increase observed from agricultural to non-agricultural soils for different PTEs were $3.19 \%$ for $\mathrm{Fe}, 25.3 \%$ for $\mathrm{Mn}, 63.8 \%$ for $\mathrm{Cu}, 13.5 \%$ for $\mathrm{Cn}, 49.8 \%$ for $\mathrm{Pb}$, $79.6 \%$ for $\mathrm{Ni}, 35.8 \%$ for $\mathrm{Co}, 32 \%$ for $\mathrm{Cd}$, whereas 2.02 and 2.99 times increase were found for $\mathrm{Zn}$ and As respectively. From non-agricultural to industrial soils the percentage change observed for different PTEs were $89 \%$ for $\mathrm{Zn}, 2.03 \%$ for $\mathrm{Fe}, 21.9 \%$ for $\mathrm{Mn}, 68.2 \% \mathrm{Cu}, 9.2 \%$ for $\mathrm{Cn}, 35.8 \%$ for $\mathrm{Pb}, 18.4 \%$ for $\mathrm{Co}, 30.4 \%$ for $\mathrm{Cd}$ and $43.4 \%$ for As, and 4.21 times increase in $\mathrm{Ni}$. The percentage change from agricultural to industrial soils were $5.2 \%$ for $\mathrm{Fe}, 52.8 \%$ for $\mathrm{Mn}, 24 \%$ for $\mathrm{Cn}, 60.8 \%$ for $\mathrm{Co}$ and $72.2 \%$ for $\mathrm{Cd}$, while 3.8, 2.7, 2.03, 7.5 and 4.2 times increase were found for $\mathrm{Zn}, \mathrm{Cu}, \mathrm{Pb}, \mathrm{Ni}$ and As respectively. In agricultural soils, skewness of $\mathrm{pH}, \mathrm{OC}$ and all PTEs were found less than one signifying normal distribution of data (Beaver et al. 2012). Kurtosis values of Fe, Mn and As were found above one signifying leptokurtic, while $\mathrm{pH}, \mathrm{OC}, \mathrm{Zn}, \mathrm{Cu}, \mathrm{Cn}, \mathrm{Pb}, \mathrm{Ni}$ and $\mathrm{Cd}$ showed kurtosis values less than one reflecting 
normal distribution of data (Beaver et al. 2012). In non-agricultural soils, skewness values of $\mathrm{Cn}, \mathrm{Ni}$ and Co showed strongly skewed data, while for $\mathrm{pH}$, OC and other PTEs skewness values were found less than one (Beaver et al. 2012). The kurtosis values of $\mathrm{pH}$, OC and PTEs exhibited leptokurtic kurtosis except $\mathrm{Pb}$. In industrial soils, the $\mathrm{Co}, \mathrm{Ni}, \mathrm{Cd}$ and $\mathrm{As}$ recorded skewness values less than one signifying normal distribution of data, while $\mathrm{pH}, \mathrm{OC}$ and other PTEs showed strongly skewed data. Except Co and $\mathrm{Cd}$, kurtosis values of $\mathrm{pH}$, OC and other PTEs showed kurtosis values above one, representing leptokurtic (Beaver et al. 2012). The high kurtosis of PTEs indicates that sampling sites are gathered at comparatively less values (Lu et al. 2010). High coefficient of variance values were found for PTEs, signifying that anthropogenic activities have pronounced control on the concentrations of PTEs (Kumar et al. 2019c).

3.2. Correlation analysis of potentially toxic elements in agricultural, non-agricultural and industrial soils

The person's correlation was performed on the $\mathrm{pH}, \mathrm{OC}$ and PTEs data in order to find the inter-associations among the studied parameters in agricultural, non-agricultural and industrial soils (Figure 2 A, B and C). From the results of correlation analysis in agricultural soils, it was found that $\mathrm{pH}$ and $\mathrm{OC}$ is negatively correlated with all the studied PTEs. All PTEs are positively correlated with each other in agricultural soils. In non-agricultural soils, $\mathrm{pH}$ is negatively and $\mathrm{OC}$ is positively correlated with the studied PTEs. All PTEs are positively correlated with each other in non-agricultural soils. In industrial soils, $\mathrm{pH}$ showed positive correlation with PTEs, while OC is negatively correlated with PTEs. All PTEs showed positive relationship with each other in industrial soils signifying that PTEs have same source in all soil types. The positive correlation among PTEs is accredited to similar type of sources accountable for PTEs concentration and anthropogenic activities such as industrial activities like spring industry, iron rods factory, iron industry, cycle industry etc., 
and agricultural practices like usage of pesticides, fertilizers and herbicides are responsible for PTEs concentration (Kumar et al. 2019c; Keshavarzi \& Kumar 2019a).

\subsection{Principal component analysis and non-metric multidimensional scaling of} potentially toxic elements in soils

Principal component analysis (PCA) was performed on the PTEs data to find source apportionment among PTEs. The first four components of PCA with Eigen values were found above one, accounts $72.9 \%$ of the variation. The loadings and loading plot of PCA are given in Table 2 and Figure 3. The loadings of component matrix for PTEs revealed that PC1 is dominated by $\mathrm{Mn}, \mathrm{Ni}, \mathrm{Co}, \mathrm{Cd}$ and As. PC2 is controlled by Fe and $\mathrm{Cn}$. Zn contributes to PC3, while PC4 is influenced by $\mathrm{Cu}$ and $\mathrm{Pb}$. After varimax rotation, $\mathrm{PC} 1$ is contributed by $\mathrm{Mn}, \mathrm{Co}, \mathrm{Cd}$ and $\mathrm{As}$. Fe and $\mathrm{Cn}$ are dominated by PC2. PC3 is regulated by $\mathrm{Pb}$ and $\mathrm{Ni}$. PC2 influenced by $\mathrm{Zn}$ and $\mathrm{Cu}$. Industries are responsible for most of the $\mathrm{HM}$ pollution in Ludhiana district. The area is dominated by bicycle, woollen and hosiery industries. Further, the town is known for preparation of machine tools, dying work and electroplating (Setia et al. 2020). The non-metric multidimensional scaling (NMDS) was also performed on the sampling sites on the basis of PTEs data. The results of NMDS scatter plot inferred that four points, i.e., 29, 40, 50 and 54 are unglued from the other sampling points (Figure 4a). In the sampling sites 29, 40 and 50 soils are collected adjacent to grassland, while 54 point is soil collected around the industrial zone. The stress level is less than the 0.05 (Kaur et al. 2018), indicating good fit of this data to NMDS plot (Figure 4b).

\subsection{Appraisal of pollution level of potentially toxic elements in soils}

The contamination factor $(\mathrm{CF})$, enrichment factor $(\mathrm{EF})$ and geoaccumulation index (Igeo) was enumerated to oversee the pollution level of PTEs in different soils (Table 3). On the basis of grades suggested by Hakanson (1980), the CF results for agricultural soils followed the trend as $\mathrm{As}>\mathrm{Cd}>\mathrm{Pb}>\mathrm{Ni}>\mathrm{Co}>\mathrm{Cu}>\mathrm{Zn}>\mathrm{Mn}$. Among PTEs, As and $\mathrm{Cd}$ 
showed high contamination, while $\mathrm{Pb}$ exhibited substantial contamination. In non-agricultural soils the $\mathrm{CF}$ values of PTEs followed the trend as: $\mathrm{As}>\mathrm{Cd}>\mathrm{Pb}>\mathrm{Zn}>\mathrm{Cu}>\mathrm{Co}>\mathrm{Ni}>\mathrm{Mn}$. Amid PTEs, Cd and As exhibited high contamination, whereas $\mathrm{Pb}$ showed significant contamination. The $\mathrm{Zn}, \mathrm{Cu}, \mathrm{Co}, \mathrm{Ni}$ and $\mathrm{Mn}$ showed low contamination in the study area. In industrial soils the $\mathrm{CF}$ values of different PTEs followed the trend as: $\mathrm{As}>\mathrm{Cd}>\mathrm{Ni}>\mathrm{Pb}>$ $\mathrm{Cu}>\mathrm{Co}>\mathrm{Zn}>\mathrm{Mn}$. The $\mathrm{As}, \mathrm{Cd}, \mathrm{Pb}$ and Ni showed high contamination, whereas $\mathrm{Cu}, \mathrm{Co}, \mathrm{Zn}$ and $\mathrm{Mn}$ exhibited considerable to modest contamination in the area.

The grades given by Sutherland (2000) to categorise the pollution level on the basis of $\mathrm{EF}$. The EF results of agricultural soils indicated that $\mathrm{Cd}, \mathrm{As}, \mathrm{Ni}$ and $\mathrm{Pb}$ exhibited extreme enrichment in the area, $\mathrm{Co}$ and $\mathrm{Cu}$ showed high enrichment, and $\mathrm{Zn}$ and $\mathrm{Mn}$ showed considerable enrichment of studied PTEs. In non-agricultural soils $\mathrm{Cd}, \mathrm{As}, \mathrm{Co}, \mathrm{Pb}$ and $\mathrm{Cu}$ showed extreme, $\mathrm{Zn}$ and $\mathrm{Ni}$ showed high, and $\mathrm{Mn}$ exhibited considerable enrichment respectively. In industrial soils $\mathrm{Cd}, \mathrm{As}, \mathrm{Co}, \mathrm{Ni}, \mathrm{Pb}, \mathrm{Cu}$ and $\mathrm{Zn}$ indicated extreme enrichment, while substantial enrichment showed by Mn.

Muller (1981) suggested grades to classify the pollution level on the basis of Igeo results. The Igeo results in agricultural soil indicated that $\mathrm{Cd}, \mathrm{As}, \mathrm{Co}, \mathrm{Ni}, \mathrm{Pb}, \mathrm{Cu}$ and $\mathrm{Zn}$ showed extreme pollution, while Mn exhibited high pollution in the area. In non-agricultural and industrial soils all studied PTEs showed extreme pollution in the studied area.

Pollution index (PI) and modified pollution index (MPI) was also computed for different PTEs to find their pollution load (Figure 5 A and B). The grades suggested by Nemerow (1991) for PI and MPI and based upon that in agricultural soils $\mathrm{Zn}, \mathrm{Pb}, \mathrm{Ni}, \mathrm{Cd}$ and As exhibited severe pollution, $\mathrm{Cu}$ and $\mathrm{Co}$ modest, and $\mathrm{Mn}$ showed slight pollution. In nonagricultural soils $\mathrm{Cd}, \mathrm{Pb}$ and $\mathrm{As}$ showed severe pollution, $\mathrm{Cu}$ exhibited heavily, $\mathrm{Ni}$ and $\mathrm{Co}$ modest, and $\mathrm{Zn}$ and $\mathrm{Mn}$ showed slight pollution. In industrial soils, PI values of $\mathrm{Cd}, \mathrm{As}, \mathrm{Ni}$, $\mathrm{Pb}$ and $\mathrm{Cu}$ showed severe pollution, $\mathrm{Co}$ and $\mathrm{Zn}$ showed modest, and $\mathrm{Mn}$ exhibited slight 
pollution in the studied area. The MPI values for all studied PTEs in agricultural, nonagricultural and industrial soils were found above 10, signifying severe pollution of these PTEs in the area.

\subsection{Ecological risk appraisal of potentially toxic elements in soils}

The ecological risks were enumerated by potential ecological risk (RI) and modified potential ecological risk (MRI) for different PTEs in soils (Table 4). The potential ecological risk $(\mathrm{Er})$ value of $\mathrm{Cd}$ in agricultural soils was recorded above 320, signifying very risk of this metal in the agricultural soils of study area. Er value of As showed high risk, whereas Zn, $\mathrm{Mn}, \mathrm{Cu}, \mathrm{Pb}, \mathrm{Ni}$ and $\mathrm{Co}$ showed low risk in the area. In non-agricultural soils, $\mathrm{Cd}$ exhibited very high risk, As showed high risk, and $\mathrm{Zn}, \mathrm{Mn}, \mathrm{Cu}, \mathrm{Pb}, \mathrm{Ni}$ and $\mathrm{Co}$ exhibited low risk. In industrial soils, $\mathrm{Cd}$ and As showed very high risk, Ni reflected modest, and $\mathrm{Zn}, \mathrm{Mn}, \mathrm{Cu}, \mathrm{Pb}$ and Co showed low risk in the study area. On the basis of grades used by Kumar et al. (2018) for classification of ecological risk and on the basis of these grades it was inferred that Mn, $\mathrm{Zn}$ and Co showed low ecological peril for all samples. Cu showed low to modest ecological risk in the area. The modified potential ecological risk (mEr) of $\mathrm{Cd}$, $\mathrm{As}$ and $\mathrm{Pb}$ in agricultural soils indicated very high risk, $\mathrm{Cu}, \mathrm{Ni}$ and $\mathrm{Co}$ showed high risk, and $\mathrm{Zn}$ and $\mathrm{Mn}$ exhibited low risk. In non-agricultural soils, $\mathrm{Cd}, \mathrm{As}, \mathrm{Pb}$ and $\mathrm{Cu}$ showed very high risk, $\mathrm{Zn}$ and $\mathrm{Mn}$ exhibited low risk, and $\mathrm{Ni}$ and $\mathrm{Co}$ showed high risk in the area. In industrial soils, $\mathrm{Cd}, \mathrm{As}, \mathrm{Ni}$ and $\mathrm{Pb}$ showed very high risk, $\mathrm{Zn}$ and $\mathrm{Mn}$ displayed low risk, and $\mathrm{Cu}$ and Co showed high risk in the area. The results of ecological risk indicated inferred that $\mathrm{Cd}$ is the vital pollutant in the area.Our results on ecological risk appraisal are in corroboration with Pandit et al. (2020) and Kumar et al. (2018). They also reported in their studies that $\mathrm{Cd}$ is the main contaminant responsible for polluting the soils. On the basis of RI and MRI values the trend followed by different soils are as follows: industrial soil > non-agricultural soil > agricultural soil. 


\section{Conclusions}

The present study concluded that industrial soils recorded highest concentration of potentially toxic elements in contrast with non-agricultural and agricultural soils. After comparison of industrial soils with Indian background values and Poland soil limits, it was revealed that $100 \%$ samples were surpassed their values for $\mathrm{Zn}, \mathrm{Mn}, \mathrm{Pb}, \mathrm{Ni}$, $\mathrm{Co}$ and $\mathrm{As}$, while $80 \%$ for $\mathrm{Cu}$, and $60 \%$ for $\mathrm{Cd} .97 .5 \%, 82.5 \%, 47.5 \%, 100 \%$ and $42.5 \%$ sampling sites surpassed their contents for $\mathrm{Zn}, \mathrm{Mn}, \mathrm{Ni}, \mathrm{Pb}$ and $\mathrm{Co}$ in comparison with their limits in agricultural soils. Similarly, in non-agricultural soils 100\% sampling sites surpassed their values for $\mathrm{Zn}, \mathrm{Mn}, \mathrm{Pb}, \mathrm{Ni}, \mathrm{Co}$ and $\mathrm{As}$ in contrast with their limits. Pearson's correlation analysis indicated that PTEs have same source of origin and mainly industrial activities in the area contribute PTEs level in the soil. The results of CF, EF, Igeo, PI, MPI, RI and MRI showed that As and Cd are the main pollutants in the soils of study area.

\section{Acknowledgement}

The authors are highly thankful to I.K. Gujral Punjab Technical University, Jalandhar for providing the necessary supports and facilities to carry out this work.

\section{Declarations}

Funding: Not Applicable

Ethics approval and consent to participate: Not applicable

Consent for publication: Not applicable

Availability of data and materials: The datasets used and/or analysed during the current study are available from the corresponding author on reasonable request. 
Author Contribution:

The paper was conceived and designed by JS and CP. The sampling of soil and its analysis was done by FV and SS. VK and RK analyzed data and proofread the manuscript. SSD assisted in the analysis of the soil sample. The critical revisions and the final version were done by JS and CP. All authors have read and approved the final manuscript.

\section{References}

Beaver MB, Beaver JR, Mendenhall W. 2012. Introduction to probability and statistics. New Delhi (India): Cengage Learning.

Hakanson L. 1980. An ecological risk index for aquatic pollution control. A sedimentological approach. Water Res 14(8):975-1001. doi:10.1016/0043-1354(80)90143-8 
Hammar, Harper, D.A.T., Ryan, P.D., 2001. PAST: paleontological statistics software package for education and data analysis. Paleontologia Electronics 4 (1), 9 palaeo-electronica.org/2001_1/past/issue1_01.htm

Hashmi, M. Z., Yu, C., Shen, H., Duan, D., Shen, C., Lou, L., \& Chen, Y. (2013). Risk assessment of heavy metals pollution in agricultural soils of siling reservoir watershed in Zhejiang province, China. BioMed research international, 2013.

Heidari, A., Kumar, V., \& Keshavarzi, A. (2019). Appraisal of metallic pollution and ecological risks in agricultural soils of Alborz province, Iran, employing contamination indices and multivariate statistical analyses. International journal of environmental health research. Doi:10.1080/09603123.2019.1677864

Hou, D., O’Connor, D., Igalavithana, A. D., Alessi, D. S., Luo, J., Tsang, D. C., \& Ok, Y. S. (2020). Metal contamination and bioremediation of agricultural soils for food safety and sustainability. Nature Reviews Earth \& Environment, 1-16.

Jackson ML (1967) Soil chemical analysis. Prentice Hall of India Pvt. Ltd, New Delhi

Jansson, J. K., \& Hofmockel, K. S. (2019). Soil microbiomes and climate change. Nature Reviews Microbiology, 1-12.

Kaur, R., Kaur, R., Sharma, A., Kumar, V., Sharma, M., Bhardwaj, R., \& Thukral, A. K. (2018). Microbial production of dicarboxylic acids from edible plants and milk using GC-MS. Journal of Analytical Science and Technology, 9(1), 21

Kawatra, B. L., \& Bakhetia, P. (2008). Consumption of heavy metal and minerals by adult women through food in sewage and tube-well irrigated area around Ludhiana city (Punjab, India). Journal of Human Ecology, 23(4), 351-354. 
Keshavarzi, A., \& Kumar, V. (2019a). Ecological risk assessment and source apportionment of heavy metal contamination in agricultural soils of Northeastern Iran. International journal of environmental health research, 29(5), 544-560.

Keshavarzi, A., \& Kumar, V. (2019b). Spatial distribution and potential ecological risk assessment of heavy metals in agricultural soils of Northeastern Iran. Geology, Ecology, and Landscapes, 1-17.

Kopittke, P. M., Menzies, N. W., Wang, P., McKenna, B. A., \& Lombi, E. (2019). Soil and the intensification of agriculture for global food security. Environment international, 132, 105078.

Kumar, R., Sharma, S. K., Thakur, J. S., Lakshmi, P. V. M., Sharma, M. K., \& Singh, T. (2010). Association of air pollution and mortality in the Ludhiana city of India: a time-series study. Indian journal of public health, 54(2), 98.

Kumar, V., Pandita, S., Sharma, A., Bakshi, P., Sharma, P., Karaouzas, I., Bhardwaj, R., Thukral, A.K., \& Cerda, A. (2019a). Ecological and human health risks appraisal of metal(loid)s in agricultural soils: a review, Geology, Ecology, and Landscapes. Doi.org/10.1080/24749508.2019.1701310

Kumar, V., Sharma, A., Kaur, P., Kumar, R., Keshavarzi, A., Bhardwaj, R., \& Thukral, A. K. (2019b). Assessment of soil properties from catchment areas of Ravi and Beas rivers: a review. Geology, Ecology, and Landscapes, 3(2), 149-157.

Kumar, V., Sharma, A., Kaur, P., Sidhu, G. P. S., Bali, A. S., Bhardwaj, R., \& Cerda, A. (2019c). Pollution assessment of heavy metals in soils of India and ecological risk assessment: A state-of-the-art. Chemosphere, 216, 449-462.

Kumar, V., Sharma, A., Minakshi, Bhardwaj, R., \& Thukral, A. K. (2018). Temporal distribution, source apportionment, and pollution assessment of metals in the 

International Journal, 24(8), 2162-2181.

382

Lu X, Wang L, Li LY, et al. 2010. Multivariate statistical analysis of heavy metals in street dust of Baoji, NW China. J Hazard Mater 173(1-3):744-9. doi:10.1016/j.jhazmat.2009.09.001.

Mahey, S., Kumar, R., Sharma, M., Kumar, V., \& Bhardwaj, R. (2020). A critical review on toxicity of cobalt and its bioremediation strategies. SN Applied Sciences, 2(7), 112.

Muller G. 1981. The heavy metal pollution of the sediments of Neckars and its tributary: A stocktaking. Chemiker-Zeitung 105:157-64

Nelson, D. W., \& Sommers, L. E. (1996). Total carbon, organic carbon, and organic matter. Methods of soil analysis: Part 3 Chemical methods, 5, 961-1010.

Nemerow NL. 1991. Stream, Lake, Estuary, and Ocean Pollution. John Wiley and Sons, Inc., New York, USA

Ogunkunle, C. O., \& Fatoba, P. O. (2013). Pollution Loads and the Ecological Risk Assessment of Soil Heavy Metals around a Mega Cement Factory in Southwest Nigeria. Polish Journal of Environmental Studies, 22(2).

Pandit, P., Mangala, P., Saini, A., Bangotra, P., Kumar, V., Mehra, R., \& Ghosh, D. (2020). Radiological and pollution risk assessments of terrestrial radionuclides and heavy metals in a mineralized zone of the siwalik region (India). Chemosphere, 126857. Doi:org/10.1016/j.chemosphere.2020.126857

Setia, R., Dhaliwal, S.S., Kumar, V., Singh, R., Kukal, S.S., \& Pateriya, B. (2020). Impact assessment of metal contamination in surface water of Sutlej River (India) on human health risks. Environmental Pollution 265 (2020) 114907. 
Sikka R, Nayyar VK. Monitoring of Lead $(\mathrm{Pb})$ Pollution in Soils and Plants Irrigated with Untreated Sewage Water in Some Industrialized Cities of Punjab, India. Bull Environ Contam Toxicol. 2016;96(4):443-448. doi:10.1007/s00128-016-1751-5

Sikka, R., Nayyar, V., \& Sidhu, S. S. (2009). Monitoring of Cd pollution in soils and plants irrigated with untreated sewage water in some industrialized cities of Punjab, India. Environmental monitoring and assessment, 154(1-4), 53-64.

Sutherland RA. 2000. Bed sediment-associated trace metals in an urban stream, Oahu, Hawaii. Environ Geol 39(6):611-27. doi:10.1007/s002540050473

Taylor, S. R., \& McLennan, S. M. (1995). The geochemical evolution of the continental crust. Reviews of geophysics, 33(2), 241-265.

Tian, K., Huang, B., Xing, Z., Hu, W., 2017. Geochemical baseline establishment and ecological risk evaluation of heavy metals in greenhouse soils from Dongtai, China. Ecol. Indicat. 72, 510e520

Troeh FR, Thompson LM. 2005. Soils and soil fertility. New Delhi: Wiley

Walter, I., Martinez, F., \& Cala, V. (2006). Heavy metal speciation and phytotoxic effects of three representative sewage sludges for agricultural uses. Environmental pollution, 139(3), 507-514.

Wcisło, E., 2012. Polish soil quality standards versus risk-based soil screening levels for metals and arsenic. Hum. Ecol. Risk Assess. 18 (3), 569e587

Yeotikar, P. V., Nayyar, S., Singh, C., Mukhopadhyay, C. S., Kakkar, S. S., \& Jindal, R. (2019). Seasonal variation in oxidative stress markers of Murrah buffaloes in heavy metal exposed areas of Ludhiana. Indian Journal of Animal Research, 53(10), 1310-1315. 
430 Figure 1 Location of study area along with different sampling sites.

431 Figure 2 Pearson's correlation analysis of potentially toxic elements in: (A) agricultural soils, 432 (B) non-agricultural soils, and (C) industrial soils.

433 Figure 3 Loading plot of PCA showing different soil variables

434 Figure 4 (a) NMDS scatter plot (95\% eclipse) of sampling sites on the basis of potentially 435 toxic elements using correlation as similarity measure and (b) NMDS Shepard 2-D plot of 436 sampling sites, stress $=0.03518, \mathrm{R} 2$ for axis $1=0.6932$ and axis $2=0.4492$.

437 Figure 5 Pollution index (A) and modified pollution index (B) of different potentially toxic 438 elements in soils

\section{Table Captions}

441 Table 1 Statistical analysis of $\mathrm{pH}$, OC and potentially toxic elements (PTEs) in soils 442 collected from study

443 Table 2 Principal component analysis of potentially toxic elements

444 Table $3 \mathrm{CF}, \mathrm{EF}$ and Igeo indices of potentially toxic elements

Table 4 Ecological risk assessment of potentially toxic elements in soils collected from study

\section{Supplementary Tables}

450 Table S1 The study sites under agriculture, non-agriculture and industrial sites

451 Table S2 Soil grades for the contamination factor and enrichment

452 Table S3 Soil grades of pollution and modified pollution index

453 Table S4 Categories of (Er) and potential ecological index 


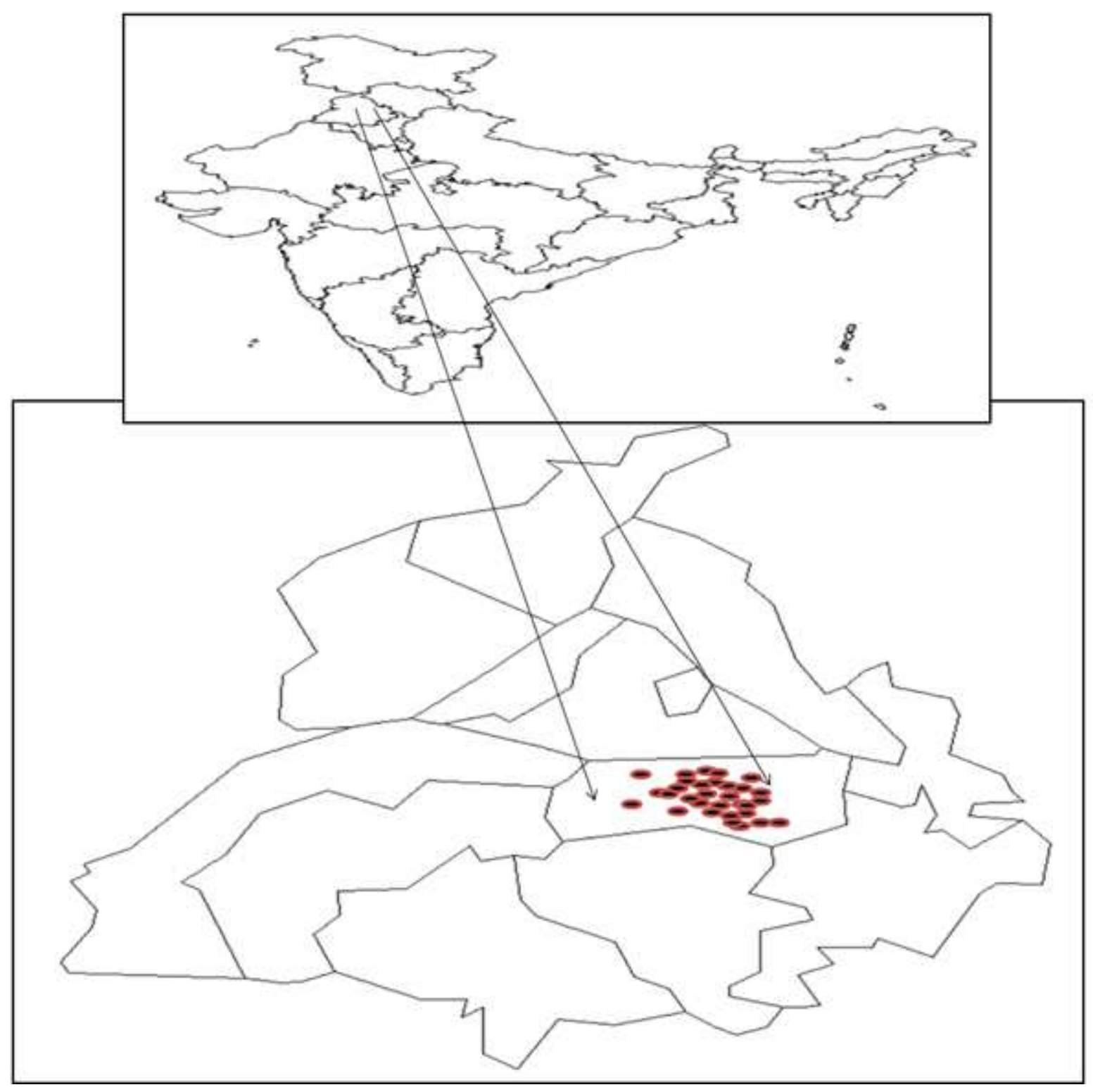

Figure 1

Location of study area along with different sampling sites. Note: The designations employed and the presentation of the material on this map do not imply the expression of any opinion whatsoever on the part of Research Square concerning the legal status of any country, territory, city or area or of its authorities, or concerning the delimitation of its frontiers or boundaries. This map has been provided by the authors. 

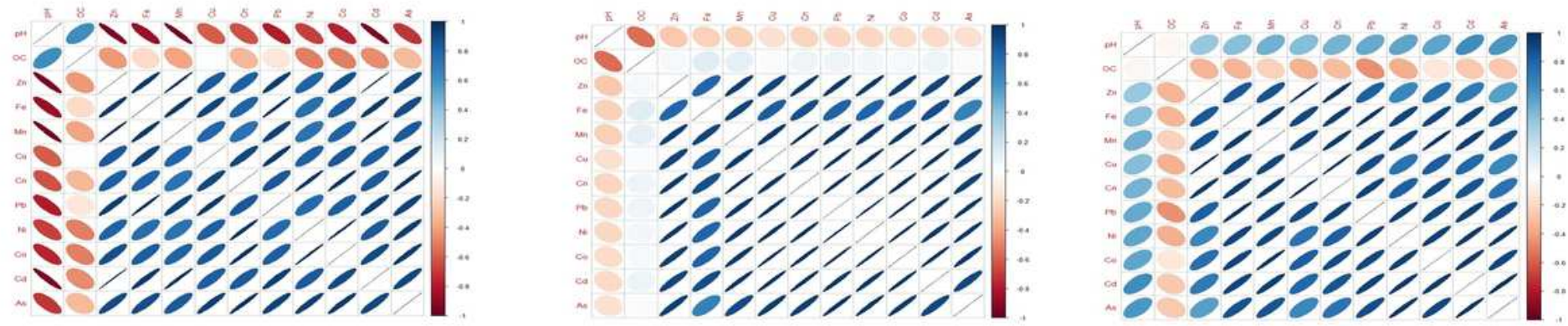

Figure 2

Pearson's correlation analysis of potentially toxic elements in: (A) agricultural soils, (B) non-agricultural soils, and (C) industrial soils.

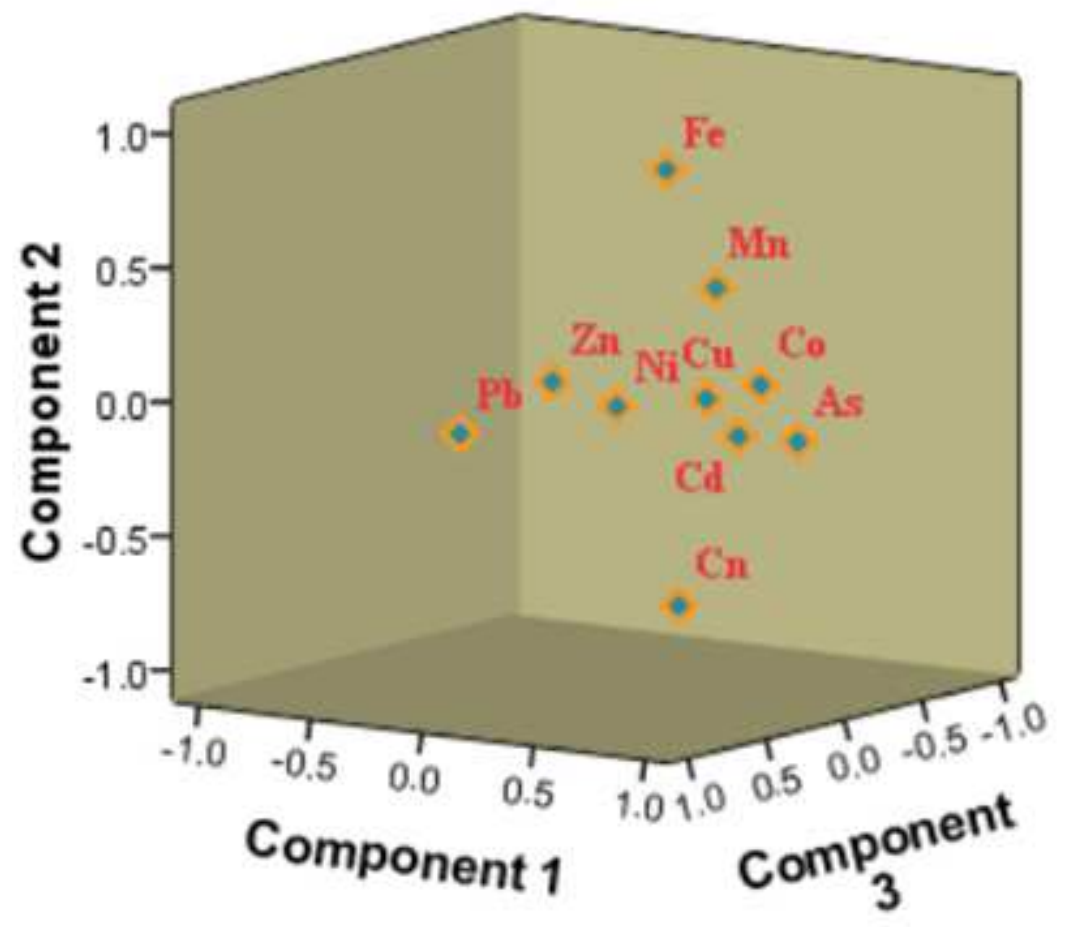

Figure 3

Loading plot of PCA showing different soil variables 

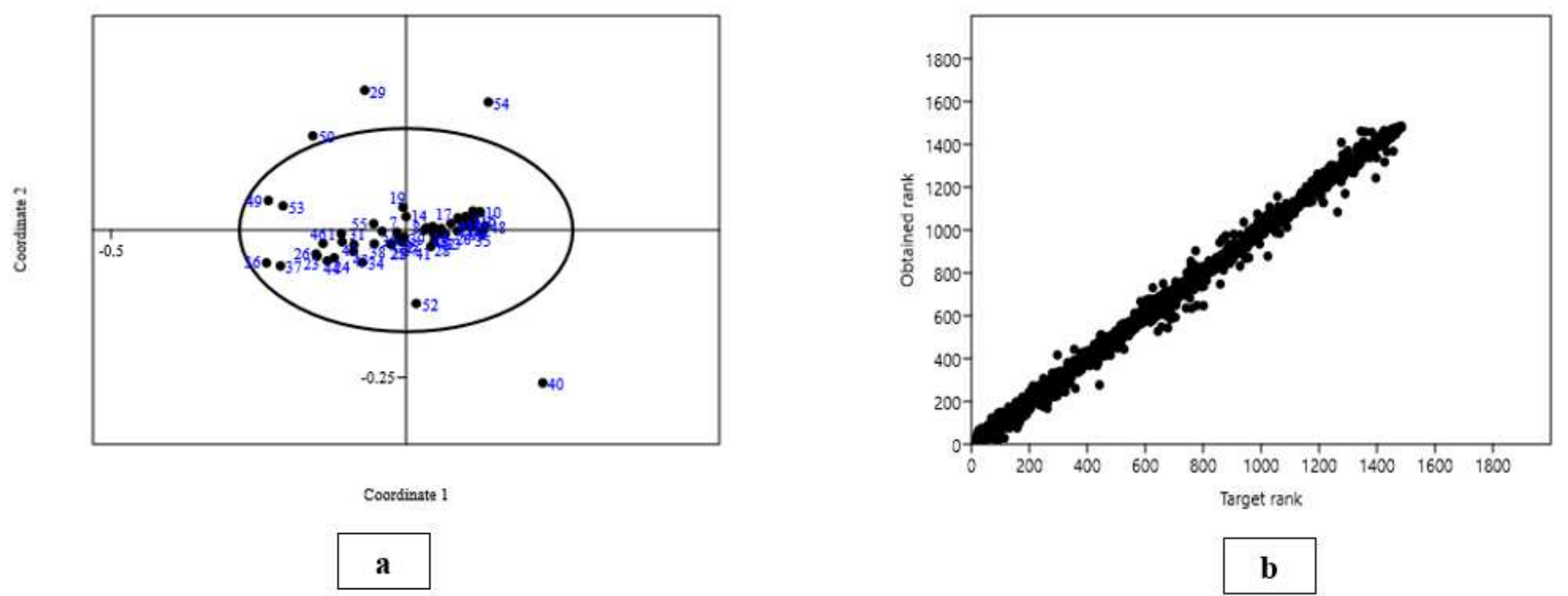

b

\section{Figure 4}

(a) NMDS scatter plot (95\% eclipse) of sampling sites on the basis of potentially toxic elements using correlation as similarity measure and (b) NMDS Shepard 2-D plot of sampling sites, stress $=0.03518, \mathrm{R} 2$ for axis $1=0.6932$ and axis $2=0.4492$.
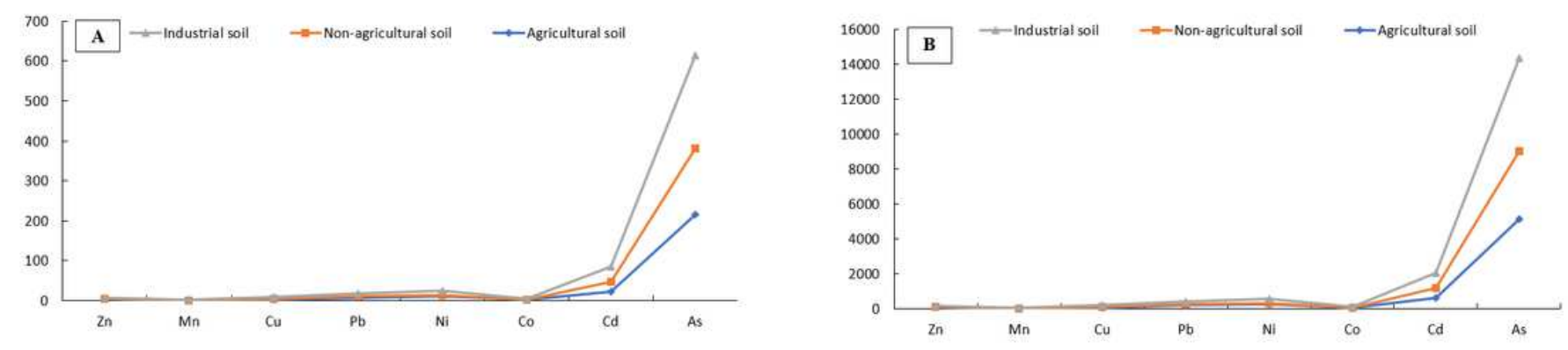

Figure 5

Pollution index $(A)$ and modified pollution index $(B)$ of different potentially toxic elements in soils

\section{Supplementary Files}

This is a list of supplementary files associated with this preprint. Click to download.

- Table3.docx

- Table4.docx

- Table1.docx 
- Table2.docx

- Supplementarytables.docx 